\title{
Service Learning as Scholarship of Engagement and Its Relationship to the Academic Reward Structure
}

\author{
Karinna M. Vernaza \\ Associate Professor \\ Dept. of Mechanical Engineering \\ Gannon University \\ Erie, PA 16541 \\ vernaza@gannon.edu \\ Barry J. Brinkman \\ Assistant Professor \\ Dept. of Computer and Information Science \\ Gannon University \\ Erie, PA 16541 \\ brinkman@gannon.edu
}

\author{
Theresa M. Vitolo \\ Associate Professor \\ Dept. of Computer and Information Science \\ Gannon University \\ Erie, PA 16541 \\ vitolo@gannon.edu
}

Scott E. Steinbrink

Associate Professor

Dept. of Mechanical Engineering

Gannon University

Erie, PA 16541

Steinbrink@gannon.edu

\begin{abstract}
Service-learning is an emerging paradigm in undergraduate education benefitting students, universities, and communities. Students benefit from the practical, hands-on experience of service utilizing the education received through their academic work; universities benefit from the good will and good publicity garnered by successful projects; communities benefit, as service-learning projects often aim to address real and pressing needs. But what of the faculty member whose task it is to identify, formulate and oversee these community projects? In this paper, the argument is made that servicelearning projects may potentially provide reward to tenure-track faculty members by inclusion in rank and tenure dossiers. Service-learning projects can be included within the Boyer Model of Scholarship under the scholarship classifications of Application, Teaching, or Engagement. The paper concentrates particularly on the Engagement classification. Additionally, risks to the faculty member choosing to use service-learning as a promotion or tenure tool are discussed. The authors' own service-learning activities are described and discussed as an example.
\end{abstract}

Index Terms - Boyer Model of Scholarship, Community-Based Scholarship, Rank and Tenure, Service-Learning in Engineering.

\section{MODELS OF SCHOLARSHIP}

Commitment to scholarship enhances the students experience both in and out of the classroom. Broadly defined, scholarship must enrich the quality of the overall academic experience. The term scholarship, for many years, was restricted to a very narrow set of activities. The need to define faculty work in a broader platform, to realistically recognize all the functions of academic life, became evident in the 1990s. ${ }^{1,2}$ As the landscape of the number and types of higher education institutions based on the Carnegie Classification presented in Table $\mathrm{I}^{3}$ is observed, it can be argued that traditional research might not reflect all the scholarly activities performed. 
Out of 4,634 higher education institutions in the United States, 6.3\% are research universities which account for the $28.2 \%$ of the total enrollment in the United States: 20,727,660.

TABLE I

SUMMARY OF THE CARNEGIE CLASSIFICATION FOR INSTITUTIONS ${ }^{4}$

\begin{tabular}{|c|c|c|}
\hline Carnegie Classifications & Number of Institutions (\%) & \% of Enrollment \\
\hline Research Universities (RU/VH, RU/H, DRU)* & $297(6.3 \%)$ & 28.2 \\
\hline RU/VH & $108(2.3 \%)$ & 13.6 \\
\hline Associate (Public and Private) & $1920(41.6 \%)$ & 39.6 \\
\hline Assoc/Pub-U-MC** & $137(3.0 \%)$ & 9.6 \\
\hline Master's $(\mathrm{L}, \mathrm{M}, \mathrm{S}) * * *$ & $724(15.6 \%)$ & 22.5 \\
\hline Master's L & $413(8.9 \%)$ & 16.9 \\
\hline Baccalaureate & $810(17.5 \%)$ & 6.8 \\
\hline Special Focus Institutions & $883(18.4 \%)$ & 3.3 \\
\hline Tribal Colleges & $32(0.7 \%)$ & 0.1 \\
\hline
\end{tabular}

Note: Authors have combined Classifications into general groups disregarding the profit/non-profit status. Classifications with the largest contributions to enrollment have been individually noted.

* $\quad \mathrm{RU} / \mathrm{VH}=$ Research Universities (very high research activity)

$\mathrm{RU} / \mathrm{H}=$ Research Universities (high research activity)

$\mathrm{DRU}=$ Doctoral/Research Universities

** Assoc/Pub-U-MC = Associate's - Public suburban-serving multicampus

*** Master's/L = Master's Colleges and Universities (larger programs)

Master's/M = Master's Colleges and Universities (medium programs)

Master's/S = Master's Colleges and Universities (smaller programs)

The Carnegie Foundation for the Advancement of Teaching produced a special report authored by Ernest Boyer ${ }^{1}$ as an effort to address and provide a new vision for scholarship in higher education. Ernest Boyer provided a framework to enlarge scholarly perspectives. He argued that a new vision of scholarship was required for universities to continue to advance forward. In his book Scholarship Reconsidered, Boyer proposed a more inclusive view of what it means to be a scholar through four dimensions:

- Scholarship of Discovery

- Scholarship of Integration

- Scholarship of Application

- Scholarship of Teaching

The Scholarship of Discovery (i.e. investigation) includes basic or original research. In other words, it relates to the scholarly activities contributing new information which expands human knowledge.

The Scholarship of Integration (i.e. synthesis) encompasses scholarly activities creating connections across disciplines by seeking a better understanding of existing knowledge. These scholarly works place known information into a broader context. This category incorporates scholarly trends that can be classified as interdisciplinary, interpretive and integrative.

The Scholarship of Application (i.e. practice) encompasses scholarly activities directly connecting one's field of knowledge to the needs of society. The activities considered tend to move theory to practice, and from practice back to theory. 
The Scholarship of Teaching incorporates scholarly activities related to pedagogical practices. This category incorporates teaching trends transforming and extending the transmission of knowledge.

Clearly these four dimensions interact dynamically as they provide a framework to recognize different types of scholarly work. This framework moves away from previous perspectives in which basic research (i.e. Scholarship of Discovery) was viewed as the one and only form of scholarly activity. Under these four dimensions, community-engaged scholarship (i.e. servicelearning) would be classified under Scholarship of Application. This category requires a clear distinction between service activities and scholarly projects. ${ }^{2}$

In 1996, Boyer expanded his definition of scholarly work by including a fifth dimension, Scholarship of Engagement. ${ }^{5}$ This dimension incorporates the scholarships of discovery, integration, application, and teaching to address pressing social, civic, and ethical problems. Through this dimension, higher education becomes engaged in the issues of our times. The inclusion of the fifth dimension heightens the value and recognition to service-learning activities and community-based scholarship.

The quality of the scholarly work, in any of these dimensions, is evaluated based on the following three attributes:

1. Professional: Scholarly work is pertinent to the discipline of the individual faculty member.

2. Communicated: Scholarly work has been made known to a wider, appropriate organization/group.

3. Peer-reviewed: Scholarly work has been accepted by peers by the mechanisms of a personal invitation, document review, acceptance or acknowledgement by respected authorities in the discipline.

The above described framework provides a platform recognizing a large array of scholarly activities. Community-based scholarship fits into the four- or five-dimensional framework. Figure 1 provides a model supporting Boyer's premises and showing the interconnection between the different dimensions. 


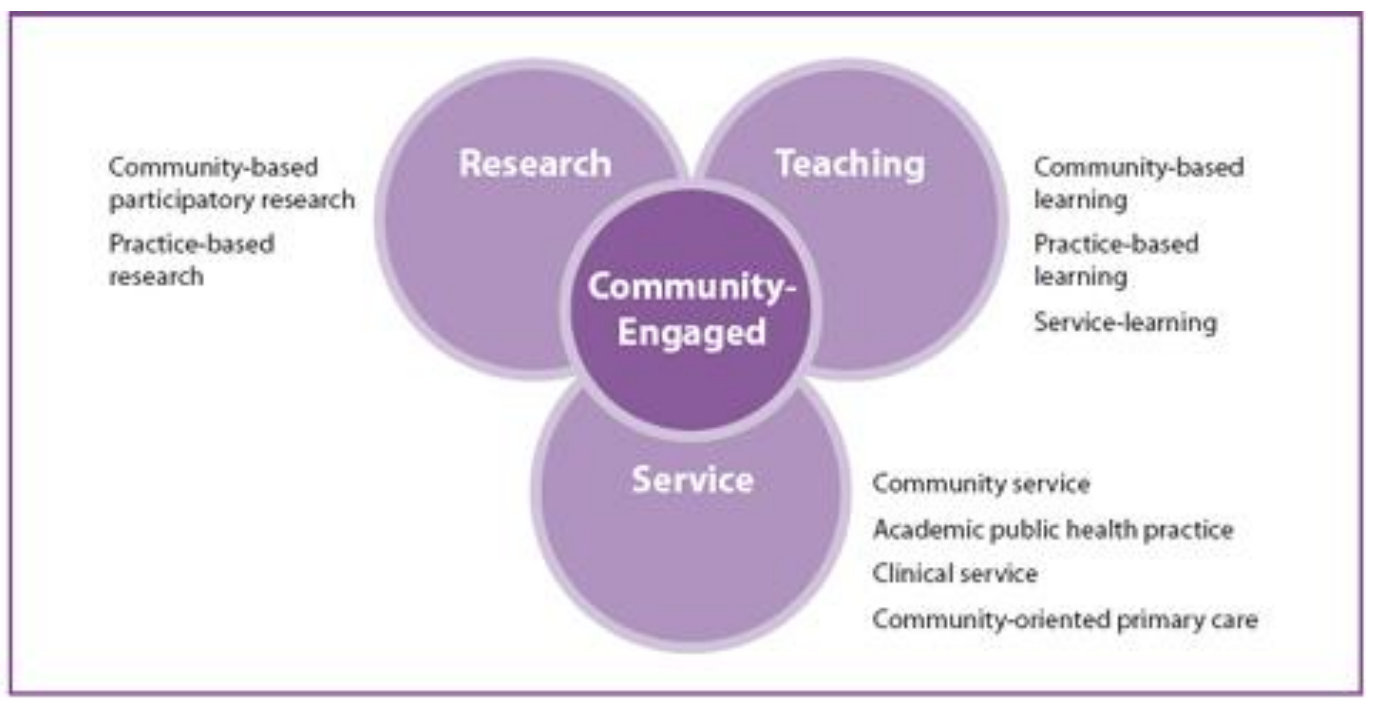

FIGURE 1

COMMUNITY-ENGAGED TEACHING, RESEARCH, AND SERVICE ${ }^{6}$

The Community-Engaged Teaching, Research, and Service platform has been adopted by a number of institutions since it recognizes the full scope of academic work. One of the first groups to recognize the need to adopt a broader definition was the health professions. ${ }^{7}$ Health professions have made the case for the recognition of community-engaged. ${ }^{8}$ Engineering schools started to formally undertake service-learning projects in the nineties. A list of programs classified as curricular efforts, certificates, and extracurricular activities is presented in Bielefeldt and Pearce ${ }^{9}$; examples of other programs are summarized in several publications. ${ }^{10,11}$ Some of these curricular initiatives are Service-Learning Integrated throughout the College of Engineering (SLICE) at the University of Massachusetts-Lowell, ${ }^{12}$ Engineering Projects in Community Service (EPICS) at Purdue University, ${ }_{14}^{13}$ Humanitarian Engineering and Social Entrepreneurship (HECE) at Penn State University, ${ }^{14}$ among many others. Recognition of service-learning activities has been provided by the National Science Foundation (NSF) who has funded many of these initiatives; for example, SLICE and EPICS have been funded by the NSF. Additionally, in 2012 the American Society for Engineering Education (ASEE) created the Community Engagement in Engineering Division which recognized the scholarly merit of community-based efforts.

A successful service-learning initiative provides faculty the opportunity for scholarly work as it enhances the student's learning. Significant efforts have been made to integrate professional or soft skills into the engineering curriculum. Service-learning provides a platform to teach effective soft skills to students coupled with technical material or content. Real life initiatives, such as community-based projects, can be easily adapted to meet the ABET, Inc. Engineering Criteria (ABET EC 3) Outcomes 3a-k. ${ }^{15}$ Specifically, seven out of the eleven outcomes can be easily connected to community-based projects. Table 2 presents these seven outcomes and examples of service-learning activities realizing them. Short descriptions of the projects are presented in the subsequent section: Service-Learning in Engineering. 
TABLE 2

PREFERRED ABET ENGINEERING CRITERIA OUTCOMES FOR SERVICE LEARNING ACTIVITIES

\begin{tabular}{|c|c|c|}
\hline \multicolumn{2}{|r|}{ Selected ABET EC3 Outcomes } & Examples of an activity associated with each \\
\hline $\mathrm{c}$ & $\begin{array}{l}\text { an ability to design a system, component, } \\
\text { or process to meet desired needs within } \\
\text { realistic constraints such as economic, } \\
\text { environmental, social, political, ethical, } \\
\text { health, and safety, manufacturability, and } \\
\text { sustainability }\end{array}$ & $\begin{array}{l}\text { All projects produce an implementation of an } \\
\text { engineering need. For example, in the 2011-13 } \\
\text { Barber Center Kit Project, electrical control } \\
\text { components for part sorting are designed and } \\
\text { developed }\end{array}$ \\
\hline d & $\begin{array}{l}\text { an ability to function on multidisciplinary } \\
\text { teams }\end{array}$ & $\begin{array}{l}\text { Teams are composed of an array of majors } \\
\text { collaborating for at least two years }\end{array}$ \\
\hline $\mathrm{f}$ & $\begin{array}{l}\text { an understanding of professional and } \\
\text { ethical responsibility }\end{array}$ & $\begin{array}{l}\text { Meeting stakeholder needs requires comprehension } \\
\text { of professional and ethical responsibilities }\end{array}$ \\
\hline $\mathrm{g}$ & an ability to communicate effectively & $\begin{array}{l}\text { Each project on a semester-basis presents project } \\
\text { development to stakeholders, peers, and professional } \\
\text { audiences through oral presentations or posters at } \\
\text { internal and public venues such as ASEE section } \\
\text { conferences }\end{array}$ \\
\hline $\mathrm{h}$ & $\begin{array}{l}\text { the broad education necessary to } \\
\text { understand the impact of engineering } \\
\text { solutions in a global, economic, } \\
\text { environmental, and societal context }\end{array}$ & $\begin{array}{l}\text { All projects have a societal impact serving non-profit } \\
\text { regional stakeholders; some may have international } \\
\text { applications }\end{array}$ \\
\hline $\mathrm{i}$ & $\begin{array}{l}\text { a recognition of the need for, and an } \\
\text { ability to engage in life-long learning }\end{array}$ & $\begin{array}{l}\text { The broad-scope projects involving multiple } \\
\text { disciplines strengthen the awareness of life-long } \\
\text { learning. Out of the } 17 \text { graduates of the program } \\
\text { and the university to date, three have entered } \\
\text { graduate studies, } 18 \% \text {. }\end{array}$ \\
\hline $\mathrm{j}$ & a knowledge of contemporary issues & $\begin{array}{l}\text { Publication forums communicating projects have } \\
\text { generated inquiries from other stakeholders with } \\
\text { similar needs emphasizing the commonality of the } \\
\text { issues. For example, inquiries from two different } \\
\text { universities have been received requesting the plans } \\
\text { of the 2010-12 Sediment Collection Device }\end{array}$ \\
\hline
\end{tabular}

Several authors have mapped the eleven ABET EC 3 Outcomes to service-learning activities. ${ }^{16}$ Satisfying all the outcomes in the criteria requires a rigorous technical component in the community-based project.

\section{CONNECTING WITH INSTITUTIONAL REWARD STRUCTURES}

Since service-learning initiatives are conducted by faculty as a pedagogical approach, the faculty members will be analyzing the benefit the service-learning efforts give to their careers. The faculty members may highly value the outreach and community realism of the effort, but they must be cognizant of the parameters for advancement and tenure at their institutions. Ernest 
Boyer mentions the attention faculty members must give the reward structures at their institutions when considering service-learning. ${ }^{17}$

Each institution defines its own evaluation criteria for defining a "successful" academic and for rewarding the effort. Beyond monetary rewards, many institutions' reward structures involve conferring tenure and obtaining promotion through the professoriate ranks. ${ }^{18}$ In 2009-2010, the percentage of institutions using a tenure system was $47.8 \%$, down from $55.0 \%$ in ten years. The percentage is significantly higher across all levels of public higher education $(71.2 \%$ of the $47.8 \%)$ as compared to not-for-profit institutions $(57.1 \%)$ and for-profit (1.5\%). However, in doctoral-granting institutions - the typical producers of the professoriate -- tenure continues to be a significant rite of passage (99.5\%, if public; 83.8\%, if not-for-profit). ${ }^{19}$ Even though the ranks of the professoriate have been declining due to employment of part-time, adjunct, or non-tenuretrack instructors, the majority of schools continue to offer promotion through professor ranks as a facet of their advancement structures. The connection of promotion to tenure-tracks is also defined by each institution. Regardless, though, institutions having a large staff of contingent appointments ${ }^{20}$ have grown to be the norm.

For service-learning to be embraced by institutions, the paradigm needs to be accepted by the full-time faculty involved in governance and setting the parameters of the reward structure. Any criteria used by the faculty to evaluate tenure and promotion requires objective artifacts and documentation to validate the work by internal and external parties. The Boyer Model identifies the nature of the artifact as needing to be peer-reviewed, professional, and communicated - the triad of attributes - for the work to be fully recognized.

Of the five types of scholarship within the Boyer Model, the Scholarship of Discovery and Scholarship of Integration quite easily provide artifacts fitting the triad. The results of Scholarship of Discovery are germane to the discipline owning the problem; the identification of the result as being valuable must be done by peers within the discipline for its recognition, and communicating the result is gladly done by the faculty of such a result. Likewise, the Scholarship of Integration also easily fits the triad with results having an implication across multiple disciplines and having been reviewed and valued by professionals from these multiple disciplines.

With the Scholarship of Application, the faculty are seeking ways to apply knowledge to social issues with the intent of obtaining new knowledge - new awareness about the relationships of the world in a context. As such, the faculty need to define a theoretical structure to assess the value of the application to an issue of the "real-world". The role of peer-review, then, is to confirm and accept the theoretical structure and its evidence. Once the community of peers has accepted the hypothesis and the validation process for testing the hypothesis, then communication follows. For instance, if a faculty member is hypothesizing that the communication processes of autistic children will improve after interacting with speaking-robots, the faculty member needs to describe the phenomenon to be observed. Finally, Scholarship of Teaching embodies a similar required approach as Scholarship of Application: the social issue is improved teaching/learning, a theoretical structure needs to be proposed to connect the manipulated variables of a situation with outcomes to be sought, and evidence of the manipulation and the outcomes must be reported. Classic errors in Scholarship of Application and of Teaching arise from not identifying the theoretical system a priori and, hence, not generating evidence to support the hypothesis. For instance, a professor may change the delivery mode of a class to asynchronous, distance delivery, but never define parameters for proving 
learning has benefited. Without defined parameters, the most one can provide to peers about the professional situation is anecdotal: the situation occurred.

Of the five types of scholarship within the Boyer Model, the Scholarship of Engagement tends to be weak in naturally manifesting the triad of peer-reviewed, professional, and communicated work. The engagement activities - like teaching activities - might absorb the focus of the scholar and a theoretical statement about how to assess the value of the engagement may be lost. Boyer's Model of Scholarship does not release academics from the scientific method, just enables a broadened field of inquiry. With Scholarship of Engagement, the field of inquiry to evaluate becomes the quality of the engagement. Academics simply must define a learning outcome and provide evidence of the change - the learning - being exhibited.

However, academics often find themselves involved in an engagement project and have not considered the student learning aspects. For instance, a community-map of service opportunities began as an outreach effort by the university. As its requirements grew, the effort became a class project. The development and deployment effort included phases of paid-work and studentwork. As the project morphed from semester to semester, going through new technologies and different participants, the project could not be used as scholarship due to its lack of learning analysis. The students involved in the project during the class project did learn, but no evidence was assessed. The example also suffers from the confusion when university service becomes a class project with elements of consulting. In another example, a first-year engineering seminar involved a service project with the students designing and building free, mini reading-libraries for sites in the community. The students definitely had learning experiences, but how their encounters could be recorded as service-learning in engineering had not been defined. The project had an impact on the enthusiasm of the students. Whether the project influenced their awareness of the community needs, the issues of design, or the complexities of shared deployment could not be reported to peers in the profession. Service projects have the potential to supply evidence for Scholarship of Engagement, but not without the intention to do so.

The concept of defining learning outcomes and providing evidence for teaching efforts is well entrenched in higher education, particularly with accredited programs and institutions favoring assessment-based evidence. Portfolios and reflection journals can be the evidence used. By themselves, these artifacts are not sufficient, however. A rubric capturing the theoretical structure of the learning needs to be used for a completed assessment. Bielefeldt, Paterson, and Swan (2010) offer a set of learning outcomes and assessment approaches for academics to consider as vehicles for assessing service-learning. The suggested outcomes span the range of behaviors covered by ABET standards; the academic need only to plan the change in the students' behaviors benefitting the most from a project-based service-learning encounter.

One point of confusion surrounding service-learning is its relationship to service activities. Without the theoretical structure making the connection between observed behaviors and outcomes sought, then many instances of engagement become solely service activities because the change wanted in the students - the learning - is not articulated and assessed.

\section{BARRIERS TO SERVICE-LEARNING IN ENGINEERING}

The ability to legitimately include scholarly activities associated with service-learning within a rank or tenure application has been addressed in foregoing sections of this paper. Nevertheless, scholarship based upon service-learning activities present risks which must be considered by junior faculty members. The intent of this section is to address perceptions of risk by faculty 
members who might be interested in pursuing a service-learning component of scholarship. Perceived risks may cause junior faculty members to choose to delay or reduce service-learning activity until after successful achievement of academic tenure.. Important opportunities may be forever lost because much of the idealism often found in new faculty members can be expected to be tempered over time, and because a faculty member who has developed a fruitful scholarship activity might in many cases be unwilling to transition to a service-learning agenda. . Of course, it is also possible a more experienced and less fearful academic may emerge at the completion of the pre-tenure period; such an academic may be more willing to engage in servicelearning. Nevertheless, the perceived risks associated with the choice of "service-learning" as a tenure-earning scholarly activity should be considered, if service-learning is to be encouraged as an academic pursuit. Among these risks are the need to rely upon others for favorably-reportable results, potential difficulties in obtaining personal recognition for effort and contribution, development of valid assessment instruments (to be able to adequately demonstrate the value of efforts), concerns of insufficient publicity, potential high degree of time commitment, institutional strategic policy mismatch regarding service-learning efforts, and inherent biases on the part of potential reviewers of promotion and tenure applications.

Funding issues are ubiquitous in scholarly pursuits. Funding requirements for servicelearning efforts will differ from those of discovery efforts, and funding must be sought other than from the typical sources. Those differences may be substantial but otherwise, the financial obstacle is not unique to scholarship based upon service-learning.

Many of the non-financial risks have varying effect, depending upon project scale. Here we define the scale of projects by consideration of the number of people who stand to benefit from the project outcome and the technical difficulty of the project. Large-scale projects impact a large number of people and require a good deal of technical expertise. They also tend to receive a good deal of public notice.

Projects - large or small - may fail to achieve their objectives. Failure risk is of course not unique to service-learning-based scholarship, and thus does not in-and-of-itself provide a deterrent to scholarship based upon service-learning. New faculty members who come from a research perspective may, however, be more accustomed to the failure risks associated with traditional scholarship, and thus may be frightened away from potentially very impactful servicelearning projects.

Failure risk may be attenuated by careful selection of projects and project teams, but the presence (or absence) of teams can induce new concerns. For faculty members working solo or in small groups, small-scale projects might be expected to carry a smaller failure risk than largescale projects. For larger projects, failure risk may perhaps be made acceptably low by use of larger teams. But failure risk cannot be fully eliminated simply by using larger teams and may in some cases be exacerbated by the addition of new team members, as interpersonal dynamics become more complicated.

In the case of service-learning, however, the faculty member does not truly have the ability to work alone, and must include students in the working group. Thus service-learning projects are always collaborative. In addition to students, however, most projects will have external clients and many may have to answer to various governmental agencies, each of which may have its own needs and interests. Thus, collaboration would be expected to be the norm for all service projects, and service-learning in particular. If the failure risk materializes for a collaborative project, then all team members must potentially share the blame, regardless of which specific team members might be most responsible for the failure. This blame-sharing extends also (and 
perhaps especially) to the faculty-member in charge of overseeing the project. Thus there is a risk not only that the project will fail, but that a competent faculty member may be forced to suffer for the mistakes of others. In a single phrase, the expected blame sharing might be termed lack of differentiation.

As project scale increases, lack of differentiation may be expected to be a more prevalent risk. Common aphorisms such as "many hands make light work," or "two heads are better than one" point to a general wisdom that teams are stronger than individuals. Thus, collaborative projects might be expected to stand a better chance of succeeding, in comparison to individual efforts. Nevertheless, collaboration teams can still fail if key collaborators prove unequal to their tasks. There is thus a risk of project failure induced by collaboration. Still, many new faculty members who may embark upon service efforts will gravitate towards large-scale projects, because collaboratively-minded faculty members will often integrate themselves into groups of colleagues already working on large-scale projects and grander projects are more likely to appeal to students' desires. But because of lack of differentiation, the need to rely upon others for personal success may make service-learning projects unattractive as part of a strategy for promotion.

If a collaborative project succeeds in meeting its goals, there is nevertheless a risk to the new faculty member if the faculty member cannot specifically document his personal roles, inputs and results, or cannot garner significant publicity for her own specific part of the project. For any large-scale project worthy of significant publicity, it will typically be the principal players who receive the credit. Good leaders will always acknowledge the contributions of others, but the mere presence of a faculty member on a successful team cannot be well argued as a worthy result for promotion or tenure consideration. This situation is another case of risk due to lack of differentiation.

One answer to the problems of large scale is simple, but unattractive: reduce the scale of projects undertaken. But small-scale projects have their own risks and weaknesses, with regard to rank and tenure considerations. One significant risk has been alluded to above - local projects tend to garner only local attention. Reviewers of rank and tenure dossiers may be inclined to view local projects unfavorably, when those projects are of necessity placed beside works which reviewers consider to be more "significant." Such short-shrift consideration is errant, and a welldone project is enormously valuable, regardless of scale. However reviewers may often possess the unfortunate human tendency towards inappropriate and/or inaccurate comparison - although this problem probably also applies for more traditional scholarship activities as well.

Neither should it be forgotten: scholarly work must have been communicated, if it is to be well-received by review committees. Oakes ${ }^{21}$ lists in Chapter 7 seven journals and five conferences which accept articles on service-learning research and exemplars of service-learning projects. A search of both the 2012 and 2013 Journal Citation Reports, however, yielded no information on Journal Impact Factors for these seven journals. ${ }^{22}$ While this lack of information does not imply a lack of quality for the journals, it may render scholarly merit harder to prove within a promotion dossier. The present authors know of no venues for publication of service project results undertaken outside the service-learning domain. In view of the concern for the "splash factor" associated with large- versus small-scale projects and a potential paucity of wellknown venues for publication of service results, Rank and Tenure Committee members may view the communication of results as unremarkable. Here again, this attitude may be a case of inherent bias, but fair or unfair, the reality of the bias must be considered; it presents yet another personal risk associated with service-learning as a scholarly activity. 
In addition to the personal risks of service-learning projects undertaken during the pre-tenure period, there are other challenges to be considered, which provide barriers. These additional challenges tend to be political and economic: the need to interact with governmental agencies (especially for projects outside the country of the faculty members' residence), exigencies of travel, the need to restrict to appropriate and transferrable technology, are some examples. While these barriers are probably surmountable, they are not trivial, and may be quite daunting.

\section{SEECS AS SERVICE-LEARNING IN ENGINEERING}

The Scholars of Excellence in Engineering and Computer Science (SEECS) program at Gannon University initiated its first cohort of 20 students in fall 2009. SEECS is an interdisciplinary, multi-year, mixed academic-level offering which provides an opportunity for students in one of the majors in the School of Engineering and Computer Science. SEECS is funded through NSF Scholarships in Science, Technology, Engineering, and Mathematics (S-STEM). Students awarded SEECS scholarships are required to attend a zero-credit seminar where specific development and learning outcomes are realized in a team-based, project-based approach. The SEECS seminar is structured around three components: engineering design, professional development, and personal development.

While the two development facets are valued, the engineering design component is the pivotal experience connecting and building not only engineering competency but also personal confidence. Emphasizing the service-learning aspect of the seminar, the design projects benefit regional non-profit organizations. The design activities pair the freshmen cohort with the seniors; the sophomores with the juniors. Through these pairings, the students learn from each other while working on a real-world problem. Hence, the learning becomes relevant and the scholars excel as they share the intellectual, problem-solving aspects of design for an organization valuing their contribution. Further details concerning the seminar and overall program design can be found in an earlier paper by the authors. ${ }^{23}$

At this time, four design projects have been fostered by the SEECS seminar and have been completed.

- The first project was the redesign and construction of a new ramp for kayaks and canoes to support the activities of the Bayfront Maritime Center. BMC supports various organizations (such as high schools, middle schools, scouts, YMCA) with educational programs that build small watercraft. $^{24}$

- The second project undertaken and completed by SEECS students was the design and construction of a bicycle-powered electrical generator. The stakeholder for this project was Gannon University, specifically the Gannon Goes Green initiative, a campus-wide effort to improve environmental sustainability. ${ }^{25}$

- The third project supports the mission and activities of Pennsylvania Sea Grant. ${ }^{26}$ One of the functions of Pennsylvania Sea Grant is to monitor the water quality of the streams and creeks that flow into Presque Isle Bay and Lake Erie. The project created a device to collect suspended sediment from the creeks and streams for required analyses to ascertain sediment characteristics after storm events.

- The fourth project supports the vocational services of the Barber National Institute, ${ }^{27}$ which serves children and adults with disabilities. One of the ways adults with disabilities are assisted by the Barber Institute is by employment in the form of piece-work assignments while being supervised by Barber Institute professionals. ${ }^{28}$ Kit assembly is a common packaging task for the workers. The SEECS project provided a device to assist an intellectually-disabled client handling a kit-assembly task. 
The authors provide a more complete description of the first four projects in another paper. ${ }^{29}$ This paper also discusses how projects are chosen and building relationships with community partners.

A fifth project will be finalized during the 2013-2014 academic year. The project is affiliated with Habitat for Humanity. ${ }^{30}$ The home designs used by Habitat are standardized and aim to be highly energy efficient. The quality of the in-house ventilation of a home is the trade-off for a tightly constructed house. The SEECS project involves (1) an assessment of the overall ventilation system of the home's design and (2) a proposition of an addition or modification to the ventilation components to help safe-guard the designed ventilation expectations.

The National Service-Learning Clearinghouse provides the following definition for servicelearning:

"Service-Learning is a teaching and learning strategy that integrates meaningful community service with instruction and reflection to enrich the learning experience, teach civic responsibility, and strengthen communities." 31

Based on this definition, the SEECS projects qualify as service-learning. The design and development process used for the projects allows the scholars to learn and utilize the engineering design process. The nature of the projects and the interaction with community users enhance civic responsibility, and the completed projects help strengthen the local and regional community.

The question relevant to this discussion, however, is whether the SEECS projects and similar projects, by themselves, can be considered Scholarship of Engagement, and whether the projects can be used by the involved faculty as part of the promotion and tenure process.

As discussed earlier, many institutions consider research, teaching, and service as necessary components a faculty member must demonstrate when applying for promotion and tenure. Without question, the SEECS projects can be used by faculty as part of the service component of their portfolio.

The further question is whether the projects themselves can be used as scholarship. The projects are professional. The students learn and then apply the engineering design process. The results of the projects are communicated to the partner organization, and a device or system is delivered to the organization. The usefulness of the device is evaluated, at least informally, by the partner organization. However, the project itself is not peer-reviewed. A project well-suited to undergraduate service-learning would rarely be advanced enough to qualify as Scholarship of Discovery or Scholarship of Integration.

However, projects such as those used in the SEECS seminars can serve as a scholarship theme in a faculty's portfolio. As indicated earlier, the SEECS co-PIs have written a paper discussing various issues relating to the SEECS seminars: how they are structured and how the projects fit into the overall structure of the seminar. ${ }^{23}$ A second paper discusses how the projects are selected and provides suggestions for establishing and maintaining relationships with community partners. ${ }^{29}$ A third paper discusses how the projects are assessed and additional assessment plans for the future. ${ }^{32}$ By writing papers and submitting them for peer-review, and thereby further communicating the information, the papers qualify as scholarship.

The projects can be a basis for the Scholarship of Teaching. Students are learning valuable lessons from the projects and are also acquiring or enhancing professional skills; however, the 
learning is not formally articulated and assessed. In order for the projects to qualify as Scholarship of Teaching, the assessment of student learning must be strengthened and expanded. Desired learning outcomes would need to be articulated prior to the start of the project, as would appropriate assessment instruments. Then, the learning experienced by the students could be formally evaluated.

\section{CONCLUSION}

Boyer's five dimensions of scholarship provide a framework recognizing scholarship as a broad set of activities, not only Scholarship of Discovery. In particular, community-based scholarship (i.e. service-learning) fits well as other forms of scholarship within the Boyer model.

Faculty wanting to do service-learning must be aware of the opportunities for scholarly recognition of the project and not be hesitant to pursue the endeavor. However, each institution's reward structure must be known and acknowledged.

Projects are not enough if they are not complemented with a peer-reviewed process that recognizes their academic merit. The bottom-line recommendation is service projects need to be fully parameterized by assessments and communicated to professional forums for gaining scholarship recognition.

The rewards of participating in community-based scholarship span a large number of areas: scholarly work, professional satisfaction, enhancement of learning environment, community benefits, amongst many more. Without a doubt, peer-reviewed, professional, and communicated scholarship can draw a large interest in service-learning activities, enhance a rank and tenure portfolio, and provide a venue for more public recognition of the engineering impact in our lives.

\section{ACKNOWLEDGEMENT}

This work is supported by the National Science Foundation Award DUE-0806735. Any opinions, findings, and conclusions or recommendations expressed in this material are those of the authors and do not necessarily reflect the views of the National Science Foundation. 


\section{ENDNOTES AND REFERENCES}

\footnotetext{
${ }^{1}$ Ernest L. Boyer, Scholarship Reconsidered: Priorities of the Professoriate (New York: Wiley, 1990).

${ }^{2}$ Boyer, Scholarship Reconsidered: Priorities of the Professoriate, 22.

3 “Carnegie Classification," Carnegie Foundation, accessed September 19, 2013, http://classifications.carnegiefoundation.org/ .

4 "Carnegie Classification: Basic Classification Summary Tables" Carnegie Foundation, accessed September 19, 2013, http://classifications.carnegiefoundation.org/summary/basic.php .

${ }^{5}$ Ernest Boyer, "The scholarship of engagement," Journal of Public Service and Outreach 1, no.1 (1996): 11-20.

6 “CCPH-Community Scholarship,” Community-Campus Partnerships for Health, accessed September 19, 2013 , http://depts.washington.edu/ccph/scholarship.html.

${ }^{7}$ Jordan, Cathy, comp., "Developing Criteria for Review of Community-Engaged Scholars for Promotion or Tenure," accessed September 19, 2013, http://depts.washington.edu/ccph/pdf_files/Developing Criteria for Review of CES.pdf.

8 “CCPH-Community Scholarship,” accessed September 19, 2013, http://depts.washington.edu/ccph/scholarship.html .

${ }^{9}$ Angela Bielefeldt and Joshua.M. Pearce, "Chapter 2 - Service Learning in Engineering," in Convergence: Philosophies and Pedagogies for Developing the Next Generation of Humanitarian Engineers and Social Entrepreneurs, ed. Thomas Colledge (International Journal for Service Learning in Engineering: Humanitarian Engineering and Social Entrepreneurship, Creative Commons Attribution-ShareAlike license: http://creativecommons.org/licenses/by-sa/3.0/., 2012), 33-34.

${ }_{10}$ Angela Bielefeldt, Kurtis G. Paterson, and Christopher W. Swan, "Measuring the Value Added from Service Learning in Project Based Engineering Education,” International Journal of Engineering Education, 26, no. 3, (2010): 535-546.

${ }^{11}$ Linda Barrington and John Duffy, "Maximizing Benefits of Service-Learning in Engineering", 2010 Proceedings of ASEE Conference, (2010).

12 "Service-Learning Integrated throughout the College of Engineering (SLICE)," University of Massachusetts Lowell, accessed September 19, 2013, http://slice.uml.edu .

13 “EPICS -- Engineering Projects in Community Service: EPICS," Purdue University, accessed September 19, 2013, http://epics.ecn.purdue.edu/ .

14 “Humanitarian Engineering and Social Entrepreneurship@Penn State University,” Penn State University, accessed September 19, 2013, http://www.hese.psu.edu .

15 “ABET - Criteria for Accrediting Engineering Programs, 2013 - 2014,” ABET, accessed September 19, 2013, http://www.abet.org/DisplayTemplates/DocsHandbook.aspx?id=3149 .

${ }^{16}$ Marybeth Lima, William C. Oakes, and John L. Gruender, Service-Learning Engineering in Your Community (Oxford, New York, 2006).

${ }^{17}$ Boyer, Scholarship Reconsidered: Priorities of the Professoriate, 79.

${ }^{18}$ Although the American Association of University Professors (AAUP) state in the "Tenure and Teaching-Intensive Appointments" Report "Tenure was not designed as a merit badge for research-intensive faculty or as a fence to exclude those with teaching-intensive commitments," the reality is that tenure has economic realities associated with it to the faculty member. "Tenure and Teaching-Intensive Appointments", AAUP, Accessed August 7, 2013, http://www.aaup.org/report/tenure-and-teaching-intensive-appointments .

${ }^{19}$ U.S. Department of Education, Institute of Education Sciences, National Center for Education Statistics, "Digest of Education Statistics, Table 274," accessed August 7, 2013, http://nces.ed.gov/programs/digest/d10/tables/dt10_274.asp .

${ }^{20}$ The AAUP define contingent faculty in the "Contingent Appointments and the Academic Profession" Report as "both part- and full-time faculty who are appointed off the tenure track.". "Contingent Appointments and the Academic Profession | AAUP," AAUP, accessed August 7, 2013., http://www.aaup.org/report/contingentappointments-and-academic-profession\#11.

${ }^{21}$ William C. Oakes, "Chapter 7 -- Learning through Service: Best Practices," in Convergence: Philosophies and Pedagogies for Developing the Next Generation of Humanitarian Engineers and Social Entrepreneurs, ed. Thomas H. Colledge (2012, International Journal for Service Learning in Engineering: Humanitarian Engineering and
} 
Social Entrepreneurship, Creative Commons Attribution-ShareAlike license:

http://creativecommons.org/licenses/by-sa/3.0/., 2012), 146-177.

${ }^{22}$ http://thomsonreuters.com/journal-citation-reports/

${ }^{23}$ Karinna M. Vernaza, Theresa M. Vitolo, Scott E. Steinbrink, and Barry J. Brinkman, "Scholars of Excellence in Engineering and Computer Science Program Phase I: Development and Implementation," Proceedings of the 2011 American Society of Engineering Education Annual Conference, June 26-29, Vancouver, British Columbia, Canada. 24 "Bayfront Maritime Center | Bayfront Maritime Center," Bayfront Maritime Center, accessed September 30, 2013, www.bayfrontcenter.org.

25 "Gannon University: Gannon Goes Green," Gannon University, accessed January 7, 2013, http://www.gannon.edu/green .

26 "PA Sea Grant," Pennsylvania Sea Grant, accessed September 30, 2013, http://seagrant.psu.edu .

27 “Autism \& Disability Support - Barber National Institute," Barber National Institute. accessed September 30, 2013, http://www.barberinstitute.org/ .

28 “Transitional Work Services - Barber National Institute," Barber National Institute. accessed September 30, 2013, http://www.barberinstitute.org/programs-services/adults/employment/transitional-work-services-adult .

${ }^{29}$ Karinna M. Vernaza, Theresa M. Vitolo, Scott E. Steinbrink, and Barry J. Brinkman, "Seeking Relevancy, Building Excellence: Service Learning in the SEECS Program, an NSF S-STEM Sponsored Project," Proceedings of the 2012 American Society of Engineering Education Annual Conference, June 10-13, San Antonio, TX.

30 "Welcome | Habitat for Humanity - Erie, PA", Greater Erie Area Habitat for Humanity, accessed September 30, 2013, http://www.habitaterie.org .

31 "What is Service-Learning? | National Service-Learning Clearinghouse," National Service-Learning Clearinghouse, accessed September 30, 2013, http://www.servicelearning.org/what-service-learning .

${ }^{32}$ Theresa M. Vitolo, Karinna M. Vernaza, Scott E. Steinbrink, and Barry J. Brinkman, "Assessing Impact without Using Grades: Quality Review of Community Engagement," Proceedings of the 2013 American Society of Engineering Education Annual Conference, June 23-26, Atlanta, GA. 